\title{
NOTES ON THE NESTS AND PREY OF SIX SPECIES OF PISON IN AUSTRALIA (HYMENOPTERA: SPHECIDAE)
}

By Howard E. Evans, ${ }^{1}$ Robert W. Matthews, ${ }^{2}$ and Allan Hook ${ }^{1}$

In the course of studies on the behavior of ground-nesting Sphecidae in Australia, we have occasionally made observations on species that make free mud nests or that accept wooden trap nests (see Krombein, 1967, for technique). Chief among these are species of the genus Pison, which is abundantly represented in Australia. We report here on six species, four of which have not previously been studied (rufipes Shuckard, westwoodi Shuckard, marginatum Smith, and a species near tibiale Smith). Data on two additional species (ignavum Turner and spinolae Shuckard) confirm and enlarge upon previously published reports. Our specimens have been compared with identified material in the British Museum (Natural History), including the types of Smith's and Turner's species. Voucher specimens have been deposited in the Australian National Insect Collections, Canberra, and at the University of Queensland, Brisbane. Some of these observations were made by Evans and Matthews during the summer of 1969-70, others by Evans and Hook during the summer of 1979-80.

\section{Pison rufipes Shuckard}

Nests of this species were located on three occasions near Brisbane, Queensland. The first two were found early in the summer (1-2 November 1979) on roots dangling from the top of steep, overhanging earthen banks not far from water. The third nest was found on the pendant branch of a tree close to water on 9 March 1980, and was doubtless made by a female of a second generation. All nests were made of dried mud and were spindle-shaped, with the long axis perpendicular to the ground, and were so covered with mud on the outside that individual cells could not be discerned on the surface. The nest on a living branch presented quite a different appearance

\footnotetext{
${ }^{1}$ Department of Zoology and Entomology, Colorado State University, Fort Collins, Colorado 80523.

${ }^{2}$ Department of Entomology, University of Georgia, Athens, Georgia 30602.

Manuscript received by the editor February 12, 1981.
} 
from the others, since the wasp had incorporated the leaf bases into its nest.

The first nest, collected near Blunder Creek, in the southern part of the city of Brisbane, was actually a group of three nests on roots only a few cm apart; we have no way of knowing whether or not all were made by one female. The three nests varied in length from 4 to $6.5 \mathrm{~cm}$ and all were about $2 \mathrm{~cm}$ wide at their maxima (Fig. 2). Over the next few weeks 16 wasps emerged from the three nests, each leaving an emergence hole about $3 \mathrm{~mm}$ in diameter. The second nest was a set of two nests, of form very similar to the first set, one $2.5 \mathrm{~cm}$ wide and 5 $\mathrm{cm}$ long, the other $2 \mathrm{~cm}$ wide and $6.5 \mathrm{~cm}$ long. This nest was collected along the Brisbane River near Somerset Dam, some $60 \mathrm{~km} \mathrm{NW}$ of Brisbane. Over the next few days we reared from this nest $3 P$. rufipes, $2 P$. westwoodi, and a miltogrammine fly, Pachyophthalmus sp. We believe that westwoodi had probably appropriated cells in a nest constructed by rufipes, as that species is known to occupy hollow cavities (see below).

The third nest was collected in late summer, also at Blunder Creek, Brisbane. It was similar in shape to the others, $7.5 \mathrm{~cm}$ long by $2 \mathrm{~cm}$ wide, but had several leaves protruding from it (Fig. 1). This nest was on a pendant Acacia branch about $1.3 \mathrm{~m}$ above the ground and a short distance from the edge of a backwater of Blunder Creek. When this nest was found a female was plastering mud over the outside; she was taken for identification. The nest was dissected and found to contain ten cells, all broadly elliptical, $6.5-8 \mathrm{~mm}$ in diameter and $8.5-12 \mathrm{~mm}$ in length. Each was separated by at least $2 \mathrm{~mm}$ of mud and from the outside of the nest by about $7 \mathrm{~mm}$ of mud.

The number of spiders per cell varied from 4 fairly large ones to 9 small ones $(\bar{x}=7.1)$. Four cells contained an egg, in each case laid longitudinally, laterally on the base of the abdomen of one of the spiders. The remaining 5 cells contained wasp larvae of various sizes. All of the 47 spiders preserved proved to be Salticidae, of the following species:

Euryattus bleekeri (Doleschall)-24

Jotus braccatus Koch-5

Saitis nigriceps (Keyserling)-18 

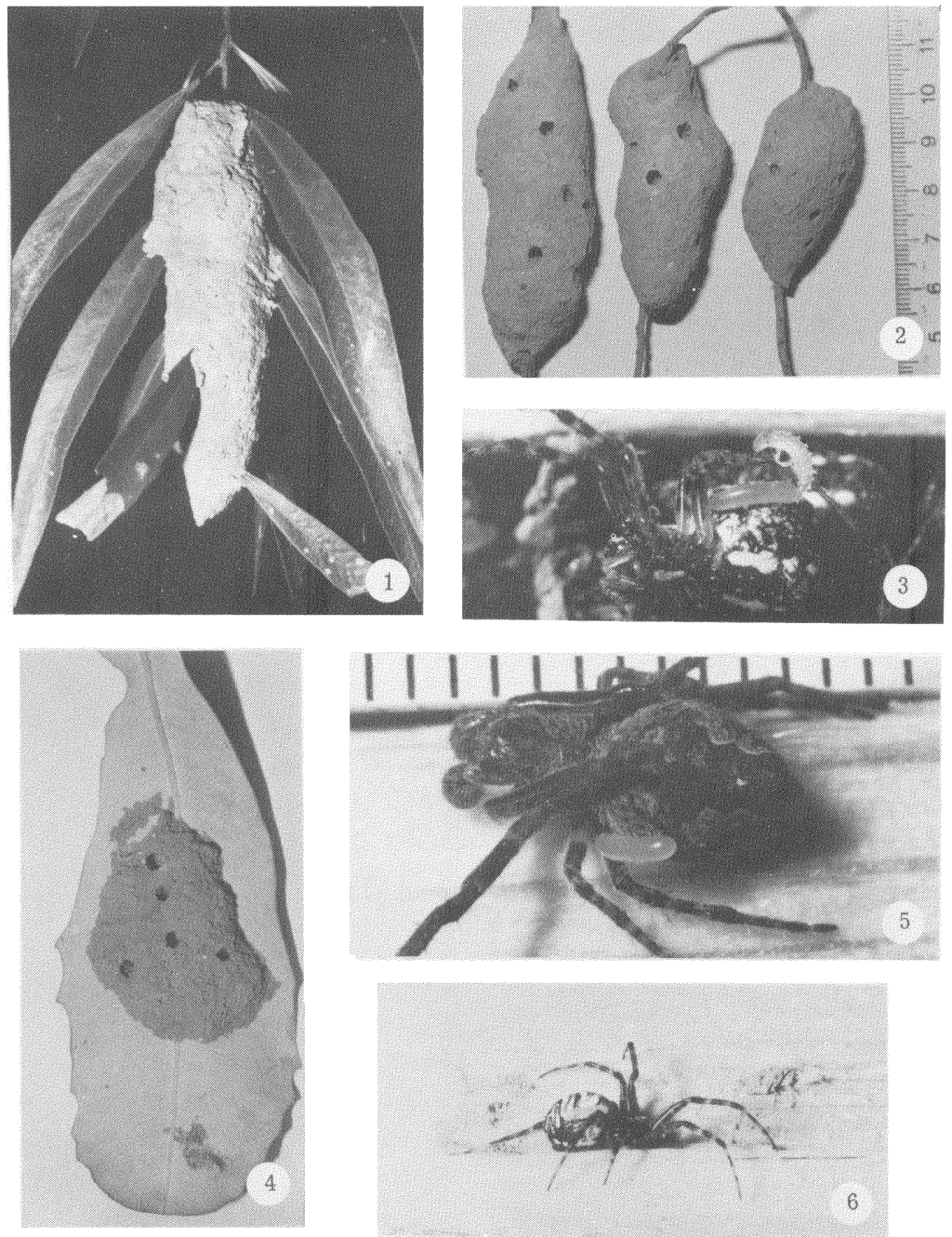

Figs. 1-6. 1. Nest of Pison rufipes on Acacia branch. 2. Nests of P. rufipes attached to pendant roots. 3 . Egg of $P$. marginatum on prey, bearing a parasitoid larva. 4. Nest of $P$. ignavum on Banksia leaf. 5. Egg of $P$. spinolae on prey. 6. Egg of $P$. marginatum on prey. 


\section{Pison ignavum Turner}

This is a widely distributed species in the Australian zoogeographic region. Williams (1945) found that in New Caledonia this species "constructs free cells of mud pellets and sometimes hangs them from rootlets exposed in a bank". We collected a nest plastered to the underside of a Banksia leaf overhanging a stagnant pool a few meters from Blunder Creek, Brisbane, in Eucalyptus-Melaleuca woodland, not far from the first nest of $P$. rufipes, cited above. This nest was 4.5 $\mathrm{cm}$ long, $3.1 \mathrm{~cm}$ wide, and $0.8 \mathrm{~cm}$ deep; it occupied about a third of the area of the leaf (Fig. 4). Seven cells could be faintly discerned beneath the lumpy surface of gray mud. This nest was collected in late November, 1979; about a month later 5 P. ignavum emerged, each leaving a small hole about $3 \mathrm{~mm}$ in diameter.

\section{Pison westwoodi Shuckard}

This very small species was reported above as having been reared from a nest of $P$. rufipes, where it had possibly usurped some cells or added cells to a completed nest. Evidently it utilizes various preexisting cavities, as we also reared the species from three trap nests set up near Canberra, Australian Capital Territory, in December 1969 and February 1970. All three trap nests had a bore diameter of 4.5 $\mathrm{mm}$, the smallest bore employed. A nest set out near the Murrumbidgee River had three cells, 9-14 $\mathrm{mm}$ in length, separated by mud partitions 1-2 mm thick; these were separated from the entrance to the boring by a long, empty cell, which was closed off by a thick mud plug. The cells contained cocoons when collected, and these gave rise to three adults the following spring. The second nest, on the window ledge of a house in Canberra, contained seven cells, varying in length form 6.5 to $12.5 \mathrm{~mm}$. All contained larvae and the remains of spiders when the nest was collected in mid-December; several adult wasps emerged in late January.

The third trap nest had been set on top of a fence rail not far from the preceding. It was sealed in mid-December and opened on 28 December. There were four cells, $6.5-12.5 \mathrm{~mm}$ in length, separated by thin mud partitions. The two innermost cells contained many tiny spiderlings, 19 and 30 per cell; evidently the egg had failed to hatch in these cells. The two outermost cells contained cocoons, one of which gave rise to a male on 27 January. Cocoons of this species measure 
6.5-8 $\mathrm{mm}$ in length and are light brown in color, of thin, parchmentlike material (Fig. 7).

\section{Pison marginatum Smith}

This species also made use of trap nests in the Canberra area during 1969-70, but the three nests we found all occupied larger borings, 6-7 $\mathrm{mm}$ in diameter. A nest collected near the Murrumbidgee River on 1 February contained cocoons which gave rise to adults on $20 \mathrm{March}$, while a second nest collected in the same area on 7 March contained eggs and larvae on the prey and ultimately produced adult wasps the following September. A third nest, on Black Mountain, Canberra, contained cocoons when harvested $24 \mathrm{March}$ and also gave rise to adults the following September. Thus there are evidently two generations a year in the Canberra area.

The three nests had from 4 to 7 cells each, the cells measuring from 12 to $19 \mathrm{~mm}$ in length and separated by mud partitions $1-2 \mathrm{~mm}$ ihick. Two of the nests were closed off by thick mud plugs, 17-18 mm thick; the third had an empty vestibular cell $30 \mathrm{~mm}$ long, closed off by a thin plug which was recessed $7 \mathrm{~mm}$ from the bore opening.

This last nest was abundantly supplied with small spiders, 5 to 9 per cell. Four of the cells contained eggs, in each case laid longitudinally on the abdomen of a spider close to the cell entrance, suggesting that it was laid on the last spider placed in the cell (Fig. 6). The following spiders were identified:

ARANEIDAE: Gea theridioides (Koch)-7 우우 Araneus lutulenta (Keyserling)-1 immature

OXYOPIDAE: Oxyopes elegans Koch-1 우

One cell from the Murrumbidgee River nest collected on 7 March had a small parasitoid larva feeding on the host egg (Fig. 3). We did not rear this successfully. Callan (1979) has reported the rhipiphorid beetle Macrosiagon diversiceps (Blackburn) as a parasitoid of the related species $P$. spinolae, and we suspect that the larva we observed was that of a rhipiphorid. The cocoons of marginatum measure 11-13 $\mathrm{mm}$ in length and are of a darker shade of gray-brown than those of westwoodi, and the walls appear thicker and firmer (Fig. 9).

\section{Pison spinolae Shuckard}

This is a relatively large species of Pison which has been introduced from Australia into New Zealand, where it is especially common. 
Callan (1979) has recently reviewed what is known of the nesting behavior and natural enemies of this species. Evidently mud cells are constructed in a variety of protected situations, often around houses, and spiders of the family Araneidae are used as prey. We reared $P$. spinolae from two trap nests placed on windowsills of a house in Canberra. Both were completed in late November, 1969; one was opened at that time and found to contain spiders bearing eggs or larvae, while the second was opened 18 December and found to contain cocoons. Adults emerged from both in late January. Both were in borings $8 \mathrm{~mm}$ in diameter. The number of cells per nest was 4-6, cell length $13-26 \mathrm{~mm}$, not including one cocoon in a very long cell in the deepest part of the boring, $61 \mathrm{~mm}$ long. The cells were separated by thin mud partitions and the nests closed off with plugs 2-4 mm thick. One nest had a $3 \mathrm{~mm}$ long vestibule cell between the last cell partition and the outer plug. Both nests had mud plugs at the extreme inner end of the boring. The number of spiders per cell varied from 5 to 12 , and the egg was placed dorsolaterally near the front of the abdomen of the spider closest to the entrance to the cell (Fig. 5). Several were saved for identification, and all proved to be Araneidae, as follows:

Araneus brisbanae (Koch)-1 ㅇ

Araneus transmarinus (Keyserling) -4 immatures

Singotypa sp.-1 ㅇ, 1 immature

Cocoons of this species measure from 10.5 to $13.5 \mathrm{~mm}$ in length (giving rise to males) and from 15.5 to $17.5 \mathrm{~mm}$ in length (giving rise to females). They differ in color from those of the preceding two species in being brown and distinctly darker at the anterior, more blunt end (Fig. 8).

\section{Pison species near tibiale Smith}

We reared individuals of this species from four trap nests, two set up on Black Mountain, Canberra, and two along the Murrumbidgee River in Australian Capital Territory. All were in bores 6-7 $\mathrm{mm}$ in diameter; one contained five cells, the other three seven each. Cells measured $12-20 \mathrm{~mm}$ in length and were separated by mud partitions $0.5-1.2 \mathrm{~mm}$ thick. Three of the nests had no outer plug when collected and were closed merely with the thin partition of the outermost cell, which was recessed $16-20 \mathrm{~mm}$ from the bore opening. One had a mud plug $10 \mathrm{~mm}$ thick, flush with the opening. A nest collected on 1 

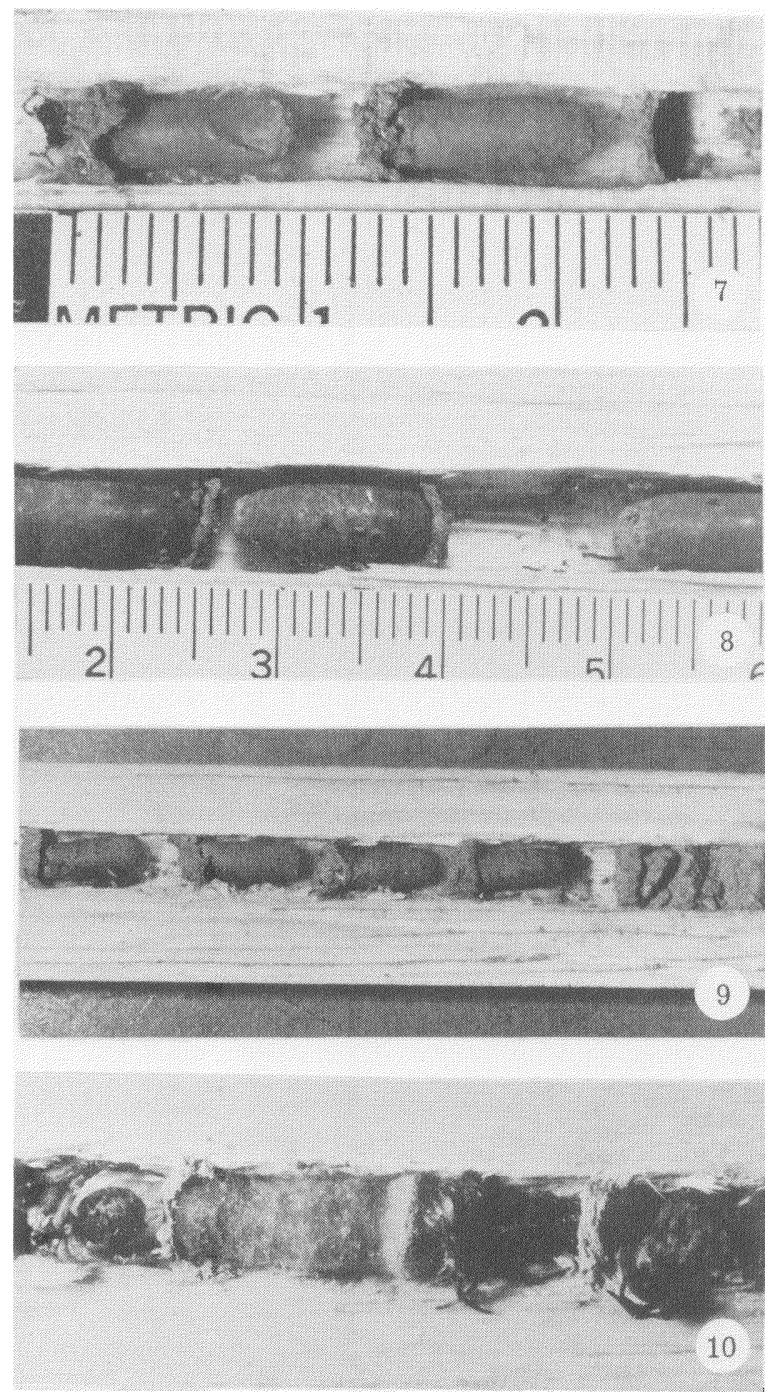

Figs. 7-10. Cocoons of Pison species in trap nests, not equally enlarged (see text for measurements). 7. P. westwoodi. 8. P. spinolae. 9. P. marginatum. 10. P. species near tibiale. 
February had larvae in all cells, the larvae being progressively smaller toward the entrance. The spiders in this nest appeared very diverse, but were not saved. The other three nests, collected 10 February-26 March, contained nothing but cocoons aside from three cells in which the egg had evidently failed to hatch; these contained 5-6 spiders each, all of them Cymbacha festiva Koch (3 우, $1 \hat{0}, 13$ immatures) (Thomisidae). Cocoons of this species measure 11-13 mm in length and are quite different in form from those of the preceding three species, being abruptly widened at the anterior end (Fig. 10).

Although our specimens key readily to tibiale in Turner's (1916) review, our impression is that several species are now being confused under that name. Our voucher specimens, in the Australian National Insect Collections, Canberra, should enable our material to be associated with the correct species name when a much-needed revision of the Australian species is available.

\section{Discussion}

The Australian species of the genus Pison evidently fall into three discrete groups with respect to nesting behavior. Members of the first group build free mud nests consisting of several cells attached to stems, roots, or leaves and coated with mud in such a way that the cells are not individually discernible on the surface. The two species rufipes and ignavum belong to this group, and it is noteworthy that both belong to a species-group in which the second recurrent vein is received at the middle of the second submarginal cell, rather than near its apex as in most Pison species. The prey of rufipes was found to consist of Salticidae.

The remaining species considered here (westwoodi, spinolae, marginatum, and sp. nr. tibiale) all accept hollow, tubular trap nests, although there is evidence that the first two are somewhat more versatile in their nesting behavior. Cells are separated by thin mud partitions and the nest is often closed off with a thick mud plug. These species appear to make extensive use of orb-weaving spiders, most records being for Araneidae, although there is one record for Oxyopidae and several for Thomisidae. The cocoons show interesting species differences, not unlike those found among North American species of the related genus Trypoxylon (Krombein, 1967; Matthews and Matthews, 1968). These cocoon differences are summarized in Table I. 
Table I. Major features of cocoons of four species of Pison.

\begin{tabular}{lccc}
\hline Species & Size $(\mathrm{mm})$ & Color & Shape \\
\hline westwoodi & $6.5-8.0$ & Light brown & $\begin{array}{c}\text { Cylindrical, more rounded } \\
\text { at posterior end than } \\
\text { at anterior end }\end{array}$ \\
marginatum & $11-13$ & $\begin{array}{c}\text { Dark gray- } \\
\text { brown } \\
\text { Brown but much } \\
\text { darker at } \\
\text { anterior end } \\
\text { Brown but } \\
\text { paler at } \\
\text { anterior end }\end{array}$ & $\begin{array}{c}\text { Like preceding, but walls } \\
\text { less thin and delicate } \\
\text { Same as marginatum }\end{array}$ \\
nr. tibiale & $10.5-17.5$ & $\begin{array}{c}\text { Abruptly expanded at } \\
\text { anterior, blunt end }\end{array}$ \\
\hline
\end{tabular}

A third group of species nests in the ground and does not use mud at any stage of nest construction; species of this group have a well developed psammophore which is used in carrying soil from the nest (Evans, 1981). Prey consists of Oxyopidae except in one species that nests in firm clay-sand (auriventre Turner) and was found to use Lycosidae.

Turner (1916) recognized about 50 species of Pison from Australia, and there are undoubtedly many more to be described. On the basis of the few species so far studied, the group appears to be a most rewarding one from the point of view of comparative behavior. It will be interesting to discover to what extent morphological differences parallel those in behavior and how much behavioral flexibility exists among the various species.

\section{ACKNOWLEDGMENTS}

The 1969-70 studies of Evans and Matthews were supported by a grant from the National Science Foundation, no. GB8746. During the summer of 1979-80 Evans held a research fellowship at the Department of Entomology, University of Queensland, and a travel grant from the National Geographic Society, while Hook had a grant for dissertation research from the National Science Foundation, no. BNS79-12602. The spiders from the Canberra area were identified by M. R. Gray of the Australian Museum, Sydney, those from Queensland by V. Davies and R. McKay of the Queensland Museum, Brisbane. 


\section{REFERENCES}

Callan, E. McC.

1979. The Sphecidae (Hymenoptera) of New Zealand. New Zealand Ent. 7: $30-41$.

Evans, H. E.

1981. Biosystematics of ground-nesting species of Pison in Australia (Hymenoptera: Sphecidae: Trypoxylini). Proc. Wash. Ent. Soc. (in press).

Krombein, K. V.

1967. Trap-Nesting Wasps and Bees: Life Histories, Nests, and Associates. Smithsonian Press. 570 pp.

Matthews, R. W. AND J. R. Matthews

1968. A note on Trypargilum arizonense in trap nests from Arizona, with a review of prey preferences and cocoon structure in the genus (Hymenopteraa, Sphecidae). Psyche 75: 285-293.

TURNER, R. E.

1916. Notes on the wasps of the genús Pison, and some allied genera. Proc. Zool. Soc. London 1916: 591-629.

WiLliams, F. X.

1945. The aculeate wasps of New Caledonia, with natural history notes. Proc. Hawaiian Ent. Soc. 12: 407-452. 

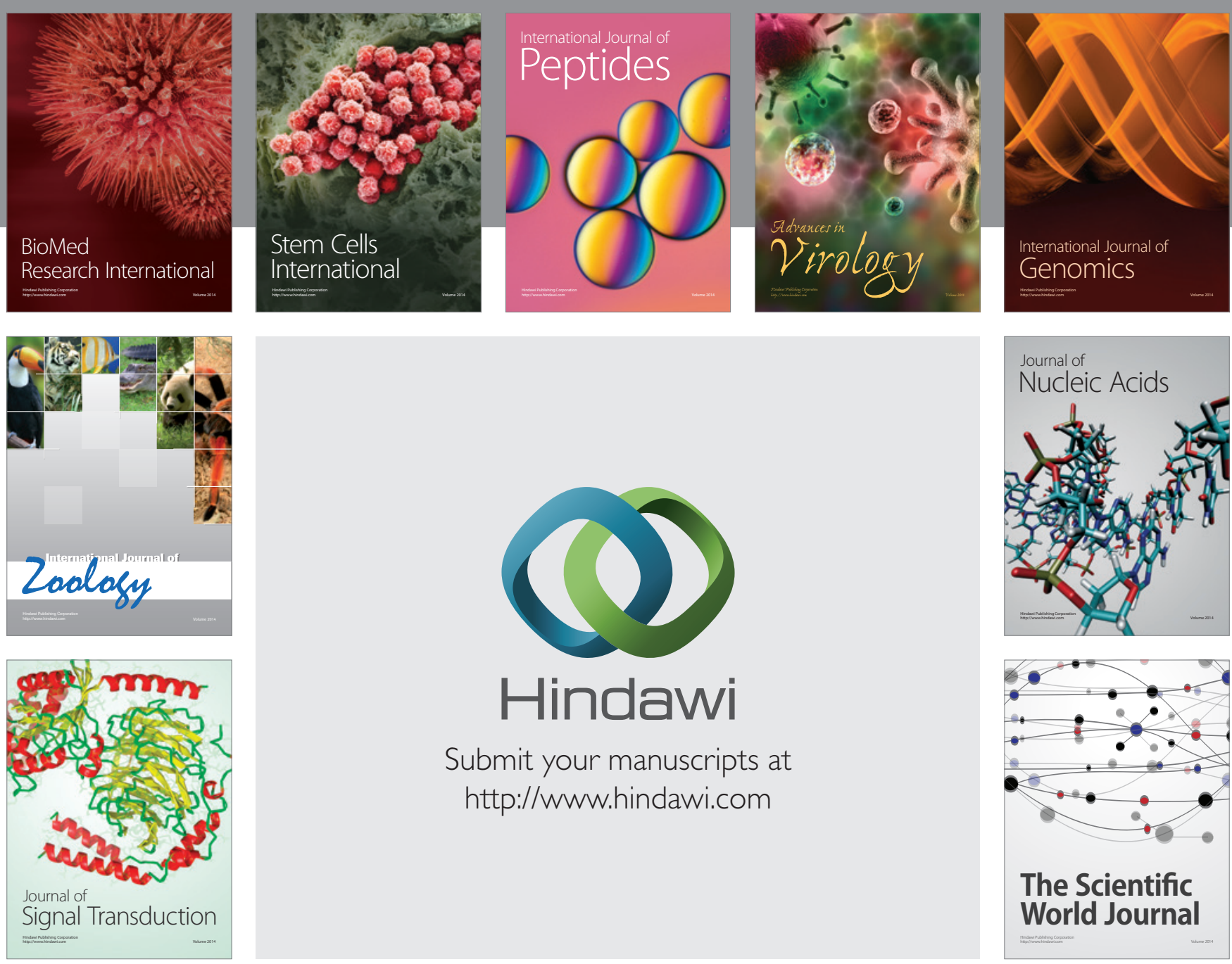

Submit your manuscripts at

http://www.hindawi.com
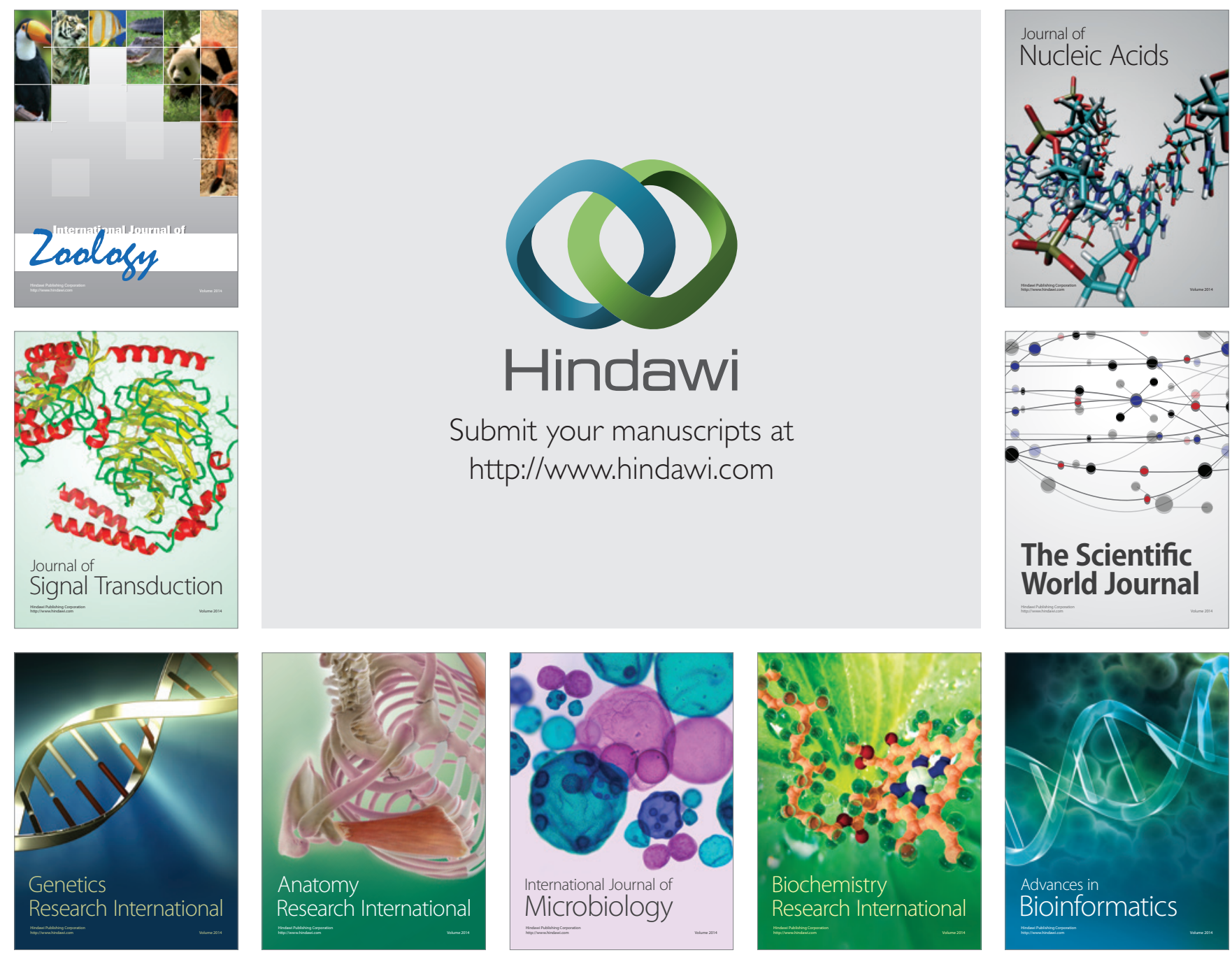

The Scientific World Journal
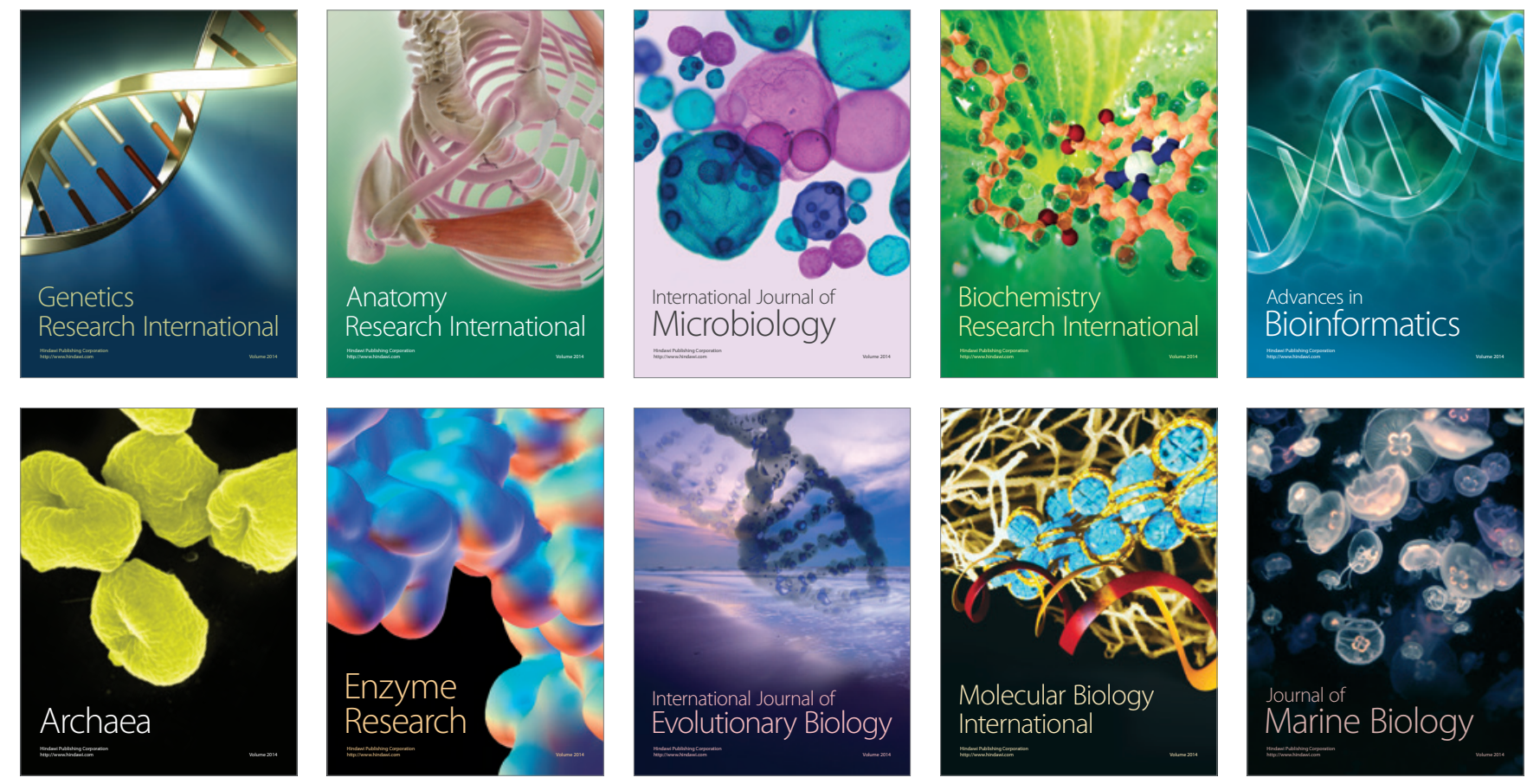